\title{
Relationships of coagulases and agglutinins in vitro and in vivo to Staphylococcus pyogenes
}

\author{
A. HENDERSON AND J. BRODIE \\ From the Laboratory, City Hospital, Aberdeen
}

SYNOPSIS Relationships are shown between coagulases and certain agglutinogens of staphylococcal serotypes. Animal experiments further show that actively acquired artificial immunity to coagulases also confers protection against challenge with 'coagulase-agglutinogen' related staphylococci, the degree of protection depending upon the route of challenge.

While working with the agglutinogens and coagulases of known staphylococcal serotypes (Henderson, 1962), it was decided to investigate the connexion. if any, between the free coagulases produced by these staphylococci and their antigenic formulae as indicated by Brodie (1957).

\section{MATERIALS}

STAPHYLOCOCCAL SEROTYPES These were obtained from the National Collection of Type Cultures and were identified as in Table I.

TABLE I

LIST OF STAPHYLOCOCCUS TYPES USED

\begin{tabular}{rc} 
Type & N.C.T.C. No. \\
\hline 1 Cowan (1939) & 8530 \\
2 Cowan (1939) & 8531 \\
3 Cowan (1939) & 8532 \\
4 Christie and Keogh (1940) & 6131 \\
5 Christie and Keogh (1940) & 6133 \\
6 Christie and Keogh (1940) & 6134 \\
7 Christie and Keogh (1940) & 6135 \\
8 Christie and Keogh (1940) & 6136 \\
9 Christie and Keogh (1940) & 6137 \\
10 Hobbs (1948) & 8722 \\
11 Hobbs (1948) & 8723 \\
12 Hobbs (1948) & 8725 \\
13 Hobbs (1948) & 8726
\end{tabular}

ANTISERA These were prepared against the 13 staphylococcal types and from them factor sera ' $a$ ', ' $c$ ', ' $e$ ', ' $f$ ', ' $i$ ', and ' $k$ ' were made, using the methods of Brodie (1957).

PREPARATION OF COAgulases Volumes of $50 \mathrm{ml}$. of Bacto heart extract broth, with the addition of $10 \%$ Seitz-filtered human serum, were inoculated with each of the 13 types of staphylococci taken from $8 \% \mathrm{NaCl}$ heart extract broth. These cultures were incubated at $37^{\circ} \mathrm{C}$. for five days, being shaken frequently throughout.

Received for publication 21 February 1963.
The coagulase produced in each was concentrated by the method of Barber and Wildy (1958), i.e., all the proteins were precipitated with 2 volumes of saturated ammonium sulphate, the precipitate redissolved in distilled water, and again precipitated with 2 volumes of ammonium sulphate; finally the deposit was taken up in distilled water.

DETECTION OF COAGULASE IN THE PREPARATIONS Before proceeding further it was necessary to prove the presence of coagulase in the preparations prepared as described above. This was difficult since, when every crude preparation was added to citrated human plasma, the clots formed immediately and as quickly disappeared. When all further attempts to secure a clot with these crude preparations produced the same type of reaction, it was concluded that a fibrin clot had formed but had so quickly changed its physical state as to be no longer visible. This result was open to interpretation as an instance of the phenomenon of coacervation. (Coacervation is that phenomenon which involves mainly hydrophilic colloids, being the separation of microscopic liquid droplets when sols of two hydrophilic colloids of opposite electric charges are mixed. These droplets may later unite to form a new viscous phase, and, if this phase has the same refractive index as that of the suspending medium, then its presence is no longer visually detectable.)

Since the simple test of clot formation on admixture of coagulase with plasma behaved in such a way that it required explanation on the basis of coacervation, some other means of confirming the presence of coagulase in the preparations was sought. Thus it was postulated that if the fibrinogen content of normal plasma is affected by coagulase, then one might expect that the clotting time would also be affected and that this might be demonstrated by a 
TABLE II

EFFECT OF ADDING COAGULASE PREPARATIONS TO CITRATED HUMAN PLASMA BEFORE PERFORMING PROTHROMBIN TIME BY $\overrightarrow{\overline{\vec{c}}}$ QUICK'S ONE-STAGE METHOD

\begin{tabular}{|c|c|c|c|c|c|c|c|c|c|c|c|c|c|}
\hline \multirow[t]{2}{*}{ Dilution of Coagulase } & \multicolumn{13}{|c|}{ Coagulase Prepared from Staphylococcal Types as Below } \\
\hline & 1 & 2 & 3 & 4 & 5 & 6 & 7 & 8 & 9 & 10 & 11 & 12 & 13 \\
\hline $\begin{array}{ll}1 & : 2 \\
1 & : 4 \\
1 & : 8 \\
1 & : 16 \\
1 & : 32 \\
1 & : 64 \\
1 & : 128 \\
1 & : 256 \\
1 & : 512 \\
1 & : 1024\end{array}$ & $\begin{array}{c}\text { NC } \\
\text { NC } \\
\text { NC } \\
150 \\
57 \\
38 \\
28 \\
28 \\
31 \\
30\end{array}$ & $\begin{array}{c}\text { NC } \\
175 \\
42 \\
34 \\
37 \\
33 \\
34 \\
31 \\
32 \\
31\end{array}$ & $\begin{array}{c}\text { NC } \\
195 \\
35 \\
30 \\
27 \\
28 \\
27 \\
28 \\
27 \\
28\end{array}$ & $\begin{array}{c}\text { NC } \\
127 \\
36 \\
30 \\
30 \\
30 \\
29 \\
30 \\
30 \\
30\end{array}$ & $\begin{array}{l}\text { NC } \\
\text { NC } \\
75 \\
30 \\
26 \\
28 \\
48 \\
30 \\
30 \\
30\end{array}$ & $\begin{array}{l}\text { NC } \\
\text { NC } \\
93 \\
32 \\
25 \\
25 \\
25 \\
25 \\
25 \\
30\end{array}$ & $\begin{array}{l}\mathrm{NC} \\
80 \\
29 \\
19 \\
19 \\
17 \\
17 \\
16 \\
16 \\
15\end{array}$ & $\begin{array}{l}\text { NC } \\
\text { NC } \\
45 \\
24 \\
19 \\
17 \\
16 \\
14 \\
14 \\
15\end{array}$ & $\begin{array}{l}\text { NC } \\
\text { NC } \\
70 \\
45 \\
26 \\
25 \\
30 \\
27 \\
25 \\
25\end{array}$ & $\begin{array}{l}\text { NC } \\
\text { NC } \\
80 \\
60 \\
50 \\
30 \\
30 \\
30 \\
30 \\
30\end{array}$ & $\begin{array}{l}\text { NC } \\
\text { NC } \\
90 \\
36 \\
23 \\
23 \\
24 \\
30 \\
22 \\
27\end{array}$ & $\begin{array}{l}\text { NC } \\
\text { NC } \\
\text { NC } \\
47 \\
28 \\
22 \\
21 \\
23 \\
23 \\
23\end{array}$ & $\begin{array}{l}\text { NC } \\
\text { NC } \\
90 \\
42 \\
34 \\
35 \\
35 \\
30 \\
32 \\
30\end{array}$ \\
\hline Control (no coagulase) & 30 & 30 & 30 & 30 & 30 & 30 & 15 & 15 & 25 & 30 & 30 & 25 & 30 \\
\hline
\end{tabular}

modification of Quick's one-stage prothrombin test (Quick, Stanley-Brown, and Bancroft, 1935), in which the addition of coagulase to normal plasma before the performance of Quick's test might be expected to prolong coagulation time. This assumption was put to the test and the results indicated that the preparations did contain coagulase. The test was done as follows.

Doubling dilutions of the coagulase preparations were made, ranging from $1 / 2$ to $1 / 2,048$. Of each dilution, $0 \cdot 1$ $\mathrm{ml}$. added was to $0.1 \mathrm{ml}$. of citrated human plasma and to this was added $0.1 \mathrm{ml}$. of Stayne's thromboplastin extract. The prothrombin time was noted after the addition of $0.1 \mathrm{ml}$. of $0.277 \%$ calcium chloride solution. The results (Table II) show that the preparations made from all 13 types of staphylococci contain coagulase.

PREPARATION OF ANTISERA TO COAGULASE PRODUCED BY THE 13 SEROTYPES One adult rabbit was injected with one of each of the 13 ammonium sulphate precipitated coagulases, making 13 rabbits in all. The intravenous route was avoided for fear of causing intravascular thrombosis, and, instead, the injections were given subcutaneously in the following doses in series:-

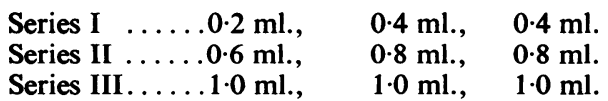

The injections were given on each of three successive days, allowing five days' rest between each series. After the ninth injection, five days' rest was again allowed, then the rabbits were bled out under pentobarbitone anaesthesia. Merthiolate was added to the sera to a final concentration of $1 / 10,000$. All the antisera were stored in the refrigerator when not in use. It was not found possible to prepare an anticoagulase serum to staphylococcus type 4 , as on four occasions it caused the death of the rabbits injected. Necropsies performed in these cases revealed that death was due to the toxicity of the preparation, and not to sepsis.

\section{METHODS AND RESULTS}

RELATIONSHIP OF COAGULASE OF A STAPHYLOCOCCAL TYPE TO ANTIGENS OF SAME TYPE If the coagulase of type 1 is the same as any of its antigens ' $a$ ', ' $c$ ', ' $e$ ', or 'i', then the prior exposure of any of the correspond- $\vec{\oplus}$ ing factor antisera to the coagulase should remove or diminish the antibody content. Such 'neutralization' tests were done by mixing the appropriate factor antisera and the crude coagulase preparations as follows:

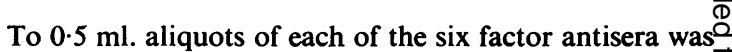
added $0.5 \mathrm{ml}$. of the concentrated coagulase preparations. $\overrightarrow{\overrightarrow{0}}$ These antisera were then titrated against each of the 133 types of staphylococci in the live condition; the tubes? were placed in the water bath at $55^{\circ} \mathrm{C}$. for four hours then left at room temperature overnight before reading. At the same time, the six antisera, untreated with coagulase, 0 were similarly set against the 13 types of staphylococci. The results are shown in Table III.

Scrutiny of the results set forth in Table III indicates a possible connexion between the coagulaseso produced by the staphylococci investigated and the antigenic formulae for them as assessed by aggluti-o nation techniques. No results are available for types 10 and 11 because these proved autoagglutinable. AO drop in titre, after the addition of coagulase, of moren than one tube has been accepted tentatively asN significant, anything less as of doubtful significance. 0 On this basis the inter-relationship of coagulases with somatic agglutinogens is given in Table IV.

Although it is tempting to interpret the results onos? the basis of inter-relationship of certain coagulases with certain somatic antigens, it would be wise too introduce a note of caution regarding the full accept-两 ance of the evidence. The crudity of the coagulased preparations must be borne in mind, particularly 
TABLE III

RESULTS OF AGGLUTINATING 13 STAPHYLOCOCCUS TYPES WITH VARYING FACTOR ANTISERA

Type of Suspension Factor Serum

\begin{tabular}{|c|c|c|c|c|c|c|c|c|c|c|c|}
\hline \multicolumn{2}{|l|}{ ' $a$ ' } & \multicolumn{2}{|l|}{ 'c $c$ ' } & \multicolumn{2}{|l|}{ ' $e$ ' } & \multicolumn{2}{|l|}{ ' $f$ ' } & \multicolumn{2}{|l|}{$' \boldsymbol{i}$} & \multicolumn{2}{|l|}{ ' $k$ ' } \\
\hline (I) & (2) & (l) & (2) & (l) & (2) & (I) & (2) & (l) & (2) & (I) & (2) \\
\hline 160 & 160 & 640 & 640 & 320 & 320 & 120 & 120 & 2,560 & 640 & 0 & 0 \\
\hline 320 & 320 & 160 & 160 & 0 & 0 & 0 & 0 & 640 & 320 & 0 & 0 \\
\hline 80 & 80 & 1,280 & 320 & 160 & 160 & O & 0 & 320 & 320 & 0 & 0 \\
\hline 0 & 0 & 80 & 80 & 0 & 0 & 640 & 0 & 0 & 0 & 80 & 0 \\
\hline 320 & 320 & 320 & 320 & 0 & 0 & 0 & 0 & 40 & 0 & 0 & 0 \\
\hline 80 & 0 & 80 & 0 & 0 & 0 & o & 0 & 40 & 0 & 160 & 0 \\
\hline 0 & 0 & 320 & 0 & 40 & 40 & 2,560 & 0 & 40 & 40 & 0 & 0 \\
\hline 160 & 0 & 640 & 160 & 80 & 40 & 0 & 0 & 1,280 & 1,280 & 0 & 0 \\
\hline 320 & 160 & 1,280 & 1,280 & 160 & 160 & 0 & 0 & 640 & 640 & 0 & 0 \\
\hline \multirow{2}{*}{\multicolumn{12}{|c|}{ Autoagglutinable }} \\
\hline & & & & & & & & & & & \\
\hline 40 & 40 & 320 & 40 & 0 & 0 & o & o & 0 & 0 & 0 & 0 \\
\hline 0 & 0 & 320 & 0 & 40 & 0 & 0 & 0 & 80 & 0 & 0 & 0 \\
\hline
\end{tabular}

$(I)=$ factor antisera

(2) = factor antisera to which coagulase of the strain to be agglutinated had been added previously

TABLE IV

POSSIBLE RELATIONSHIP BETWEEN COAGULASE(s) AND SOMATIC ANTIGEN(s) OF EACH STAPHYLOCOCCUS TYPE

Type Antigen(s) with Possible Coagulase(s) Relationship

\begin{tabular}{ll}
\hline 1 & $\mathrm{i}$ \\
2 & (i) \\
3 & $\mathrm{c}$ \\
4 & $\mathrm{fk}$ \\
5 & $\mathrm{i}$ \\
6 & acik \\
7 & $\mathrm{cf}$ \\
8 & $\mathrm{ac}(\mathrm{e})$ \\
9 & (a) \\
12 & $\mathrm{c}$ \\
13 & $\mathrm{cei}$ \\
$\mathrm{i}=$ drop in titre of more than one tube \\
(i) $=$ drop in titre of one tube only
\end{tabular}

from the viewpoint that they might contain somatic materials able to react with the factor antisera and so confuse the issue.

AGGLUTININ CONTENT OF ANTICOAGULASE SERA Since antisera to the somatic antigens of the staphylococci can be 'neutralized' by crude coagulase preparations, it was necessary to investigate the somatic agglutinin content of anticoagulase sera.

Doubling dilutions of each anticoagulase serum were made and live suspensions of 11 of the 13 staphylococcus types were added. (Types 10 and 11 were omitted on account of their autoagglutinability.) Agglutination was allowed to take place in a water bath at $55^{\circ} \mathrm{C}$. for four hours then overnight at room temperature. The results are given in Table V.

These results would seem to indicate that the antibodies to the coagulases are poor agglutinins, and that this method is unsuitable for the typing of staphylococci according to their coagulases.

TABLE V

AGGLUTINATION RESULTS USING WHOLE STAPHYLOCOCCI AGAINST ANTISERA TO COAGULASES

Suspension Type Anticoagulase Sera against Types:-

\begin{tabular}{lllllllllllll}
\hline 1 & 2 & 3 & 5 & 6 & 7 & 8 & 9 & 10 & 11 & 12 & 13
\end{tabular}

\begin{tabular}{|c|c|c|c|c|c|c|c|c|c|c|c|c|}
\hline $\begin{array}{r}1 \\
2 \\
3 \\
4 \\
5 \\
6 \\
7 \\
8 \\
9 \\
12 \\
13\end{array}$ & $\begin{array}{r}32 \\
16 \\
0 \\
8 \\
4 \\
0 \\
0 \\
32 \\
4 \\
4 \\
64\end{array}$ & $\begin{array}{r}64 \\
32 \\
4 \\
32 \\
64 \\
32 \\
4 \\
64 \\
64 \\
64 \\
128\end{array}$ & $\begin{array}{r}0 \\
0 \\
16 \\
0 \\
0 \\
0 \\
0 \\
8 \\
8 \\
0 \\
8\end{array}$ & $\begin{array}{r}32 \\
32 \\
32 \\
128 \\
32 \\
64 \\
16 \\
64 \\
64 \\
4 \\
128\end{array}$ & $\begin{array}{r}32 \\
8 \\
16 \\
128 \\
8 \\
16 \\
8 \\
8 \\
32 \\
8 \\
128\end{array}$ & $\begin{array}{r}32 \\
32 \\
16 \\
32 \\
16 \\
0 \\
16 \\
32 \\
64 \\
64 \\
64\end{array}$ & $\begin{array}{r}0 \\
0 \\
16 \\
4 \\
0 \\
0 \\
0 \\
8 \\
16 \\
16 \\
64\end{array}$ & $\begin{array}{r}0 \\
4 \\
32 \\
16 \\
4 \\
16 \\
0 \\
32 \\
64 \\
64 \\
64\end{array}$ & $\begin{array}{r}4 \\
8 \\
8 \\
32 \\
16 \\
8 \\
16 \\
16 \\
64 \\
0 \\
128\end{array}$ & $\begin{array}{r}8 \\
8 \\
8 \\
64 \\
16 \\
8 \\
16 \\
64 \\
64 \\
0 \\
128\end{array}$ & $\begin{array}{r}8 \\
0 \\
32 \\
16 \\
32 \\
16 \\
0 \\
32 \\
64 \\
64 \\
128\end{array}$ & $\begin{array}{r}32 \\
16 \\
64 \\
64 \\
64 \\
32 \\
32 \\
64 \\
128 \\
128 \\
128\end{array}$ \\
\hline
\end{tabular}

Figures are the reciprocals of the highest dilution of antisera giving complete agglutination 
ARTIFICIAL ACTIVE IMMUNITY TRIALS

The first series of rabbits was injected with coagulases and subsequently challenged with intravenously administered staphylococci. In this experiment, nine rabbits were used. Three were given the coagulase preparation made from a staphylococcus of Cowan type 1, three the coagulase from a staphylococcus of Cowan type 2 , and three the coagulase from a staphylococcus of Cowan type 3 . The saturated aqueous preparations of the coagulases were administered subcutaneously in $0.2 \mathrm{ml}$. volumes on the first three successive days of each of two weeks. After this course of six injections, a reinforcing dose of $0.2 \mathrm{ml}$. was given seven days later. One week after this injection, each rabbit received an intravenous injection of $0.2 \mathrm{ml}$. of a suspension of live staphylococci in saline, the suspension standardized to no. 4 of Brown's scale. These organisms had been previously washed thrice in saline to remove traces of preformed haemolysin.

By suitably selecting the challenge strains, rabbits protected by any of the three coagulase preparations were challenged with the three serotypes of staphylococci. The results are given in Table VI.

Failure to develop immunity to attack by a particular staphylococcus is shown, in the rabbit, by the development of renal abscesses. In the partially immune rabbit, such abscesses may form but fail to progress and healing ensues with scar formation.

Thus, partial immunity was demonstrated against serotype 3 after immunization procedures with the homologous coagulase but no protection was shown against serotypes 1 and 2. Again, injections of coagulase from serotype 2 protected against challenge with live serotypes 1 and 2 but not against $3 . \div$ Coagulase from serotype 1 failed to protect against $\overrightarrow{\vec{D}}$ live serotypes 1 and 3 but did protect against serotype 2 .

The second series of three rabbits was given the same course of injections of the coagulase preparations but the challenge injections were given subcu- $\varrho$ taneously into the flank.

Thus rabbits $A, B$, and $C$ were given a course of $\overrightarrow{0}$ coagulase from serotypes 1,2 , and 3 respectively. All $\vec{A}$ were later challenged with live suspensions $(0.2 \mathrm{ml}$.) $\vec{\omega}$ of serotypes 1, 2, and 3 injected subcutaneously into different areas of the flanks. This experiment was? controlled by injecting a fourth rabbit with the same $\vec{\sigma}$ challenge doses of the staphylococci only. The ir results are given in Table VII.

\section{DISCUSSION}

Gross (1933) was among the first to demonstrate the antigenic properties of staphylococcal coagulase. $\frac{\mathbb{D}}{3}$ Antisera to coagulase have also been prepared by Lominski and Roberts (1946), Tager and Hales (1948), Rammelkamp, Hezebicks, and Dingle (1950), $\overrightarrow{0}$ Duthie and Lorenz (1952), and Barber and Wildy (1958).

Rammelkamp et al. found antibodies towards two types of free coagulase in the serum samples from 148 medical students, and so considered that there might be at least two antigenically distinct types of $\frac{\circ}{\mathbb{Q}}$ free coagulase. Duthie (1952) and then Duthie and

TABLE VI

REACTIONS OF IMMUNITY TO COAGULASES FROM STAPHYLOCOCCUS SEROTYPES 1, 2, AND 3, AS DEMONSTRATED BY INTRAVENOUS CHALLENGE WITH LIVE STAPHYLOCOCCI OF SAME TYPES

\begin{tabular}{|c|c|c|c|c|c|c|c|c|c|}
\hline $\begin{array}{l}\text { Coagulase } \\
\text { immunity to } \\
\text { serotype }\end{array}$ & 1 & 1 & 1 & 2 & 2 & 2 & 3 & 3 & 3 \\
\hline $\begin{array}{l}\text { Challenge by live } \\
\text { serotype }\end{array}$ & 1 & 2 & 3 & 1 & 2 & 3 & 1 & 2 & 3 \\
\hline Result & $\begin{array}{l}\text { Died in } \\
6 \text { days }\end{array}$ & $\begin{array}{l}\text { Killed after } \\
3 \text { weeks }\end{array}$ & $\begin{array}{l}\text { Died after } \\
7 \text { days }\end{array}$ & $\begin{array}{l}\text { Killed after } \\
4 \text { weeks }\end{array}$ & $\begin{array}{l}\text { Killed after } \\
4 \text { weeks }\end{array}$ & $\begin{array}{l}\text { Died after } \\
1 \text { day }\end{array}$ & $\begin{array}{l}\text { Died after } \\
4 \text { days }\end{array}$ & $\begin{array}{l}\text { Killed after } \\
12 \text { days }\end{array}$ & $\begin{array}{l}\text { Killed afte } \\
4 \text { weeks }\end{array}$ \\
\hline Necropsy & $\begin{array}{l}\text { Renal } \\
\text { abscess }\end{array}$ & $\begin{array}{l}\text { Renal } \\
\text { infarct }\end{array}$ & $\begin{array}{l}\text { Renal } \\
\text { abscess }\end{array}$ & $\begin{array}{l}\text { Renal } \\
\text { infarct }\end{array}$ & $\begin{array}{l}\text { Renal } \\
\text { infarct }\end{array}$ & $\begin{array}{l}\text { Renal } \\
\text { abscess }\end{array}$ & $\begin{array}{l}\text { Faecal } \\
\text { peritonitis }\end{array}$ & $\begin{array}{l}\text { Renal } \\
\text { abscess }\end{array}$ & $\begin{array}{l}\text { Renal } \\
\text { infarct }\end{array}$ \\
\hline
\end{tabular}

TABLE VII

REACTIONS OF IMMUNITY TO COAGULASES FROM STAPHYLOCOCCUS SEROTYPES 1, 2, AND 3, AS DEMONSTRATED BY SUBCUTANEOUS CHALLENGE WITH LIVE STAPHYLOCOCCI OF SAME TYPES

\begin{tabular}{|c|c|c|c|c|}
\hline $\begin{array}{l}\text { Rabbit } \\
\text { Source of Coagulase }\end{array}$ & $\begin{array}{l}\text { Control } \\
\text { No Coagulase }\end{array}$ & $\begin{array}{l}\text { A } \\
\text { Cowan type I }\end{array}$ & $\begin{array}{l}\text { B } \\
\text { Cowan type } 2\end{array}$ & $\begin{array}{l}\text { C } \\
\text { Cowan type }\end{array}$ \\
\hline $\begin{array}{l}\text { Result of challenge with } \\
\text { Cowan type } 1 \\
\text { Cowan type } 2 \\
\text { Cowan type } 3\end{array}$ & $\begin{array}{l}\text { Abscess in } 5 \text { days } \\
\text { Abscess in } 6 \text { days } \\
\text { Abscess in } 6 \text { days }\end{array}$ & $\begin{array}{l}\mathbf{N R}^{1} \\
\mathbf{N R} \\
\mathbf{N R}\end{array}$ & $\begin{array}{l}\text { NR } \\
\text { NR } \\
\text { NR }\end{array}$ & $\begin{array}{l}\text { NR } \\
\text { MR2 } \\
\text { NR }\end{array}$ \\
\hline
\end{tabular}


Lorenz (1952) found evidence of the existence of three antigenic types of coagulase. Later, Barber and Wildy (1958) prepared in rabbits antisera to the coagulases derived from staphylococci of phage groups I, II, III, 3A, and 42E. As a result of this work they demonstrated the existence of five serologically distinct free coagulases.

Boake (1956) immunized rabbits with a coagulase derived from staphylococcus N.C.T.C. no. 8178, and challenged the rabbits with the homologous strain, by means of intravenous injections. He demonstrated a prolongation of survival time from under $\mathbf{4 8}$ hours in unprotected animals to $\mathbf{9 . 3}$ days in the protected rabbits. He also showed that this was due to circulating antibodies to coagulase, and not to antibodies to other factors such as haemolysin.

In 1962, Lominski, Smith, Scott, Arbuthnott, Gray, Muir, Turner, and Hedges demonstrated that 'rabbits immunized with coagulase from a phage group III staphylococcus were protected against challenge with group III strains, but not against challenge with group I strains. Those immunized with coagulase from phage group I staphylococci were not protected against challenge with group I or group III strains.'

In the present investigation, the results appear to indicate that several antigenically distinct types of coagulase are produced by staphylococci, and the immunizing capacity of coagulase, as measured by subsequent challenge with live staphylococci, varies with the route of challenge. Coagulases derived from staphylococci of serotypes 1,2 , and 3 are effective in protecting against challenge by any of the three serotypes when the challenge dose is given subcutaneously. Like Lominski et al. (1962) we found that when the challenge dose is given intravenously, the coagulase preparation from staphylococci of serotype 3 is effective in promoting immunity towards serotype 3 but not towards serotype 1 or serotype 2 . The coagulase from type 2 staphylococci is protective against challenge by types 1 and 2 staphylococci but not against type 3 . When the coagulase from serotype 1 staphylococci is used for immunization, it is protective against challenge by type 2 staphylococci but not against types 1 or 3 .

This failure of the coagulase derived from serotype 1 staphylococcus to protect against the homologous type is similar to the effect found by Lominski et al. (1962). It must be noted, however, that these investigators used staphylococci typed by phage methods, whereas serotypes have been employed in this investigation. Nevertheless, according to Oeding (1954) there is said to be a reasonably close relationship between phage groups I, II, and III and serotypes 1,2 , and 3 .

\section{REFERENCES}

Barber, M., and Wildy, P. (1958). J. gen. Microbiol., 18, 92.

Boake, W. C. (1956). J. Immunol., 76, 89.

Brodie, J. (1957). J. clin. Path., 10, 215.

Christie, R., and Keogh, E. V. (1940). J. Path. Bact., 51, 189.

Cowan, S. T. (1939). Ibid., 48, 169.

Duthie, E. S. (1952). J. gen. Microbiol., 7, 320.

, and Lorenz, L. (1952). Ibid., 6, 95.

Gross, H. (1933) Klin. Wschr. 12, 304.

Henderson, A. (1962). M.D. Thesis, University of Glasgow.

Hobbs, B. C. (1948). J. Hyg. (Lond.), 46, 222.

Lominski, I., and Roberts, G.B.S. (1946). J. Path. Bact., 58, 187. Smith, D. D., Scott, A. C., Arbuthnott, J. P., Gray, S., Muir, D., Turner, G. H., and Hedges, C. K. (1962). Lancet, 1, 1315.

Oeding, P. (1954). Acta path. microbiol. scand., 34, 34.

Quick, A. J., Stanley-Brown, M., and Bancroft, F. W. (1935). Amer. J. med. Sci., 190, 501 .

Rammelkamp, C. H., Hezebicks, M. M., and Dingle, J. H. (1950). J. exp. Med., 91, 295.

Tager, M., and Hales, H. B. (1948). J. Immunol., 60, 475 